\title{
Protein enrichment of jackfruit peel waste through solid-state fermentation
}

Ana Paula Moisés de Sousa ${ }^{1} \oplus$, Ana Regina Nascimento Campos ${ }^{1} \oplus$, Josivanda Palmeira Gomes ${ }^{1} \oplus$, Renato Alexandre Costa de Santana ${ }^{1} \oplus$, Aline Priscila de França Silva ${ }^{1}{ }^{\circledR}$, Antonio Daniel Buriti de Macedo ${ }^{1}$, Jaciara Dantas Costa $^{1}[0$

\footnotetext{
1 Universidade Federal de Campina Grande, Campina Grande-PB, Brasil. E-mail: anapaulinha_15_6@hotmail.com; arncampos@yahoo.com.br; josivanda@gmail.com; renatoacs@ufcg.edu.br; alinepriscila33@gmail.com; daniel_buritt@hotmail.com; dantasjaciara@gmail.com
}

ABSTRACT: The physical and chemical characteristics of jackfruit (Artocarpus heterophyllus Lam.) indicate the possibility of utilizing its wastes in the development of a new product, a nutritional supplement. Therefore, we aimed to study the protein enrichment of the waste from jackfruit peel by solid-state fermentation by using Saccharomyces cerevisiae and the experimental design associated to the response surface methodology in order to verify the effects of input variables (yeast concentration and fermentation temperature) on the protein increase. The yeast concentrations added to the substrate were of 1,3 and $5 \%$ and the used temperatures were 30,35 and $40^{\circ} \mathrm{C}$. The highest protein increase value found in the studied substrates was of $164 \%$, which corresponded to $17.1 \%$ of crude protein, dry basis, achieved after $72 \mathrm{~h}$ of processing by using a higher concentration of yeast and higher fermentation temperature. Using yeast in the semi-solid medium of the waste from jackfruit peel enables obtaining a protein supplement, which can later be used as an alternative source for animal feed.

Key words: fermentation process; jackfruit tree; jackfruit waste; protein supplement; Saccharomyces cerevisiae

\section{Enriquecimento proteico do resíduo de casca de jaca mediante fermentação semissólida}

RESUMO: As características físicas e químicas da jaca (Artocarpus heterophyllus Lam.) indicam a possibilidade de aproveitamento de seus resíduos através do desenvolvimento de um novo produto, um suplemento nutricional. Dessa forma, objetivou-se estudar o enriquecimento proteico do resíduo de casca de jaca por fermentação semissólida, utilizando a Saccharomyces cerevisiae, empregando um planejamento experimental associado à metodologia de superfície de resposta para verificar os efeitos das variáveis de entrada (concentração de levedura e temperatura de fermentação) sobre o aumento proteico. As concentrações de levedura adicionadas ao substrato foram de 1,3 e $5 \%$ e as temperaturas utilizadas 30,35 e $40{ }^{\circ} \mathrm{C}$. O maior valor de aumento proteico encontrado nos substratos estudados foi de $164 \%$, que correspondeu a $17,1 \%$ de proteína bruta, base seca, alcançado após $72 \mathrm{~h}$ de processo utilizando-se maior concentração de levedura e maior temperatura de fermentação. A utilização da levedura no meio semissólido do resíduo de casca de jaca viabiliza a obtenção de um suplemento proteico, que poderá posteriormente ser utilizado como fonte alternativa para alimentação animal.

Palavras-chave: processo fermentativo; jaqueira; resíduos de jaca; suplemento proteico; Saccharomyces cerevisiae 


\section{Introduction}

Solid wastes or by-products are inherent to the productive sector and can be generated in agriculture, in cellulose production, processing of fruits and vegetables, meat and fish, among others (Godoy et al., 2018). The world population is estimated at about 7.7 billion people, with a projection of 9.7 billion people until 2050 (UN, 2019); this said growth comes with a larger demand for food, both of plant and animal origin, implying in an increasing waste. Brazil has been negatively standing out in the organic waste production, causing serious environmental issues, social and economic problems. In order to deal with this demand, these wastes could be used for developing new food products.

Jackfruit (Artocarpus heterophyllus Lam.) is a fruit tree from Asia of great potential due its development capacity and high yield, widely cultivated throughout the tropical areas of the world, including Brazil, mainly in the Northeastern region (Haque et al., 2015). Rich in nutrients, the jackfruit has a characteristic aroma and its sweet yellow pulp is consumed both in natura and in processed form as sweets, pulps, fermented drinks, jellies, ice cream and juices. According to Anaya-Esparza et al. (2018), the jackfruit is commercialized in a minimally processed state, due to its size and handling difficulty, as it is considered the world largest fruit. However, even in this condition there is a great waste, since its peel, central axis, pivot and seeds are considered waste, corresponding in volume to more than $70 \%$ of the fruit and usually discarded or used without treatment for animal feed (Feitosa et al., 2017).

In this context, solid-state fermentation (SSF) is a promising technology in using these wastes as substrate, enabling its use in feeding animal (Rosales et al., 2018). In addition to helping reducing the environmental impact, using jackfruit wastes can be an economically interesting alternative in the feed final formulation. Among the microorganisms used for this type of fermentation, the yeast Saccharomyces cerevisiae stands out for being a protein source and not presenting pathogenic characteristics, and it can be used in both human food and animal feed (Costa et al., 2018).

Thus, the physical and chemical characteristics of an underutilized fruit such as jackfruit indicate the possibility of utilizing its wastes in the development of a new product, such as a nutritional supplement (Anaya-Esparza et al., 2018). The objective of the present research was to evaluate the protein enrichment of the peel waste from jackfruit through the solid-state fermentation process, using the $S$. cerevisiae yeast, aiming at the production of a protein supplement for animal feed.

\section{Materials and Methods}

All jackfruit (A. heterophyllus Lam.) used were purchased at the small Bujari farm, in the municipality of Cuité-PB, and sent to the Laboratory of Food Biochemistry and Biotechnology, Education and Health Center, from Federal University of
Campina Grande (UFCG). Their selection was according to the maturation stage, determined by the visual appearance of the darkened green peel and soft consistency, in addition to the characteristic smell, and manually section in order to separate its components: peel, central axis, pivot, pulp and seeds. The peel waste was crushed in an industrial blender at maximum speed, for a period of approximately $3 \mathrm{~min}$, which constituted the substrate. In all experiments, the used quantity of jackfruit peel was of $700 \mathrm{~g}$.

The microorganism used for the fermentation process was the $S$. cerevisiae yeast, a biological yeast for processing breads and their derivatives, obtained at the local commerce of the municipality of Cuité-PB. In rectangular plastic bioreactors, yeast was inoculated to the substrate, in proportions corresponding to 1,3 and $5 \%$ of the total substrate content with subsequent homogenization. The choice of these values was based on literature data referring to protein enrichment of different substrates (Peliezer et al., 2007; Alexandre et al., 2013; Araújo et al., 2017; Silva et al., 2017).

The fermentation occurred in a greenhouse with air circulation, at temperatures of 30,35 and $40{ }^{\circ} \mathrm{C}$, defined according to the optimal range for yeast growth (Polyorach et al., 2013), with a variation of $+1{ }^{\circ} \mathrm{C}$, for $96 \mathrm{~h}$. Collections of these samples were at intervals of $0,24,48,72$ and $96 \mathrm{~h}$, for the characterization of the enriched waste. Analysis of the water content, total soluble solids and crude protein were performed by following the methodology of the Adolfo Lutz Institute (2008).

In order to determine the water content (\%), the enriched waste sample was placed in an oven at $105^{\circ} \mathrm{C}$, until it reached constant weight. The crude protein content (\%) was determined by quantifying the total nitrogen of the sample, by using the Kjeldhal method. The nitrogen content was converted into protein content by multiplying the found value by the factor 6.25. Determination of total soluble solids parameter ( ${ }^{\circ} \mathrm{Brix}$ ) was performed by using a digital refractometer. All analyzes were performed in quadruplicate.

Calculation of the protein increase (PI) (\%) from the jackfruit peel was based on the protein value contained in the fresh substrate, defined as the ratio between the difference in protein value of the enriched substrate and protein value of the fresh substrate, and the initial value of crude protein in natura (Equation 1).

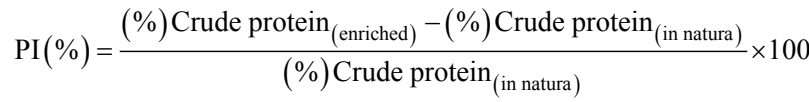

A $3^{2}$ factorial design was held, with fermentation temperature $\left({ }^{\circ} \mathrm{C}\right)$ and yeast concentration (\%) as independent variables, the coded and decoded levels are displayed in Table 1. The dependent variable was the protein increase (\%). All tests were performed in duplicate.

The software Statistica for Windows 8.0 (Statsoft., 2007) was used to generate and evaluate the experimental factorial design and the analysis of the experimental data regression. For optimizing the results, effects of the independent 
Table 1. Coded and decoded values of variables independent of $3^{2}$ factorial design.

\begin{tabular}{cccc}
\hline \multirow{2}{*}{ Variables } & \multicolumn{3}{c}{ Level } \\
\cline { 2 - 4 } & $\mathbf{- 1}$ & $\mathbf{0}$ & $\mathbf{+ 1}$ \\
\hline Temperature $\left({ }^{\circ} \mathrm{C}\right)$ & 30 & 35 & 40 \\
Yeast concentration $(\%)$ & 1 & 3 & 5 \\
\hline
\end{tabular}

variables on the measured response were modeled using the mathematical model (Equation 2), which involves the independent variables and their interactions for the measured response, generated by the $3^{2}$ factorial design.

$$
\mathrm{Y}=\mathrm{b}_{0}-\mathrm{b}_{1} \mathrm{X}_{1}+\mathrm{b}_{2} \mathrm{X}_{2}+\mathrm{b}_{12} \mathrm{X}_{1} \mathrm{X}_{2}+\mathrm{b}_{11} \mathrm{X}_{1}^{2}+\mathrm{b}_{22} \mathrm{X}_{2}^{2}
$$

In which: $Y$ is the independent variable (response), while $b_{0}$ is the intersection, $b_{1}, b_{2}, b_{12}, b_{11}$ and $b_{22}$ are the regression coefficients; $X_{1}$ and $X_{2}$ are the independent variables; $X_{1} X_{2}$ is the interaction between the variables; $X_{1}{ }^{2}$ and $X_{2}{ }^{2}$ are the quadratic terms. Analysis of variance (ANOVA) was employed for estimating the model significance $(p<0.05)$ and the individual response parameters.

\section{Results and Discussion}

During $72 \mathrm{~h}$ of fermentation, the protein increased for most of the experiments, and after that time, the crude protein content either remained the same or decreased. The highest percentage observed was in experiment 9, which reached $164 \%$ of content, corresponding to $17.1 \%$ of crude protein, on a dry basis. This experiment was conducted at a temperature of $40{ }^{\circ} \mathrm{C}$ and a $5 \%$ yeast concentration (Table 2 ).

Experiments 1, 4 and 7 were conducted at a temperature of $30{ }^{\circ} \mathrm{C}$ and yeast concentrations of 1,3 and $5 \%$, respectively. From these, experiment 7 achieved a greater protein increase of $115.9 \%$, corresponding to $11.6 \%$ of crude protein (Table 2 ), suggesting that the initial inoculum concentration had an influence on the protein gain under evaluated conditions. When conducted under the same temperature and varying the yeast concentrations, the experiments obtained different crude protein values (\%) and, consequently, different protein increase values, which corroborates with Thomas et al. (2013), since high concentrations of inoculum combined with the availability of solid substrate (carbon source) lead to positive effects regarding fermentative efficiency.

Also according to Table 2, experiments 2, 5 and 8 were kept at $35{ }^{\circ} \mathrm{C}$, with the highest protein increase content achieved in experiment 8 , with $5 \%$ yeast. The crude protein value reached $14.4 \%$, corresponding to $104.7 \%$ of protein increase. Regarding the other experiments (3 and 6) kept at $40{ }^{\circ} \mathrm{C}$, the highest protein increase values were 68.9 and $87.3 \%$, respectively. Experiments 3 and 6 had lower protein gains when compared to experiment 8 , possibly because the yeast concentrations used for inoculation of the substrate were lower, 1 and 3\%, respectively.

The highest protein gain found in the cultivated substrate was approximately 3.0 times higher, when compared to the crude protein value of the substrate in natura, corresponding to $17.1 \%$ crude protein. Analyzing the data in Table 2 , this gain was achieved after $72 \mathrm{~h}$ of cultivation, by using $5 \%$ yeast concentration and a temperature of $40{ }^{\circ} \mathrm{C}$. Apparently, the jackfruit waste has significantly increased its content to $164 \%$, which is similar to the value found by Alexandre et al. (2013) using the same microorganism to enrich the pineapple peel waste (Ananas comosus L.), in an inoculum concentration of $3 \%$ and temperature at $34{ }^{\circ} \mathrm{C}$, during $48 \mathrm{~h}$ of process. The authors also found that the enriched waste had a high dry matter $(90.27 \%)$ and protein $(20.21 \%)$ contents in relation to the in natura waste (7.61\%).

This protein increase in the jackfruit peel waste allows its utilization in protein supplements used in animal feed, since the recommended crude protein content for food used as protein supplementation for the diet of several animals is above $14 \%$, according to with the NRC (1998).

Silva et al. (2017) conducted the study of protein enrichment of umbu-cajá bagasse (Spondias spp.) and obtained $5.5 \%$ protein with $48 \mathrm{~h}$ of fermentation, by using $2 \%$ of yeast and temperature of $37{ }^{\circ} \mathrm{C}$, in an open-air oven for a period of $72 \mathrm{~h}$. This value corresponded to a protein increase of approximately 4.0 times higher, in relation to the protein value of the substrate in natura. The greatest protein increase found in the fermentation of the jackfruit waste was achieved with different conditions of yeast concentration and fermentation temperature, which shows that in addition to the physical-chemical characteristics of the substrate used; these factors have great influence on the fermentation process.

Table 2. Mean \pm standard error of crude protein, on a dry basis, of the jackfruit peel substrate, during $96 \mathrm{~h}$ of fermentation, and of the highest protein increase achieved, according to the $3^{2}$ factorial design.

\begin{tabular}{|c|c|c|c|c|c|c|c|c|}
\hline \multirow[b]{2}{*}{ Experiment } & \multirow{2}{*}{$\begin{array}{c}\text { Yeast } \\
\text { concentration (\%) }\end{array}$} & \multirow{2}{*}{$\begin{array}{c}\text { Temperature } \\
\left({ }^{\circ} \mathrm{C}\right)\end{array}$} & \multicolumn{5}{|c|}{ Crude protein (\%) } & \multirow{2}{*}{$\begin{array}{c}\text { Protein } \\
\text { increase (\%) } \\
72 \mathrm{~h}\end{array}$} \\
\hline & & & $\mathrm{Oh}$ & $24 \mathrm{~h}$ & $48 h$ & $72 \mathrm{~h}$ & $96 \mathrm{~h}$ & \\
\hline 1 & 1 & 30 & $7.3 \pm 0.2$ & $7.7 \pm 1.0$ & $7.6 \pm 0.3$ & $8.4 \pm 1.5$ & $8.6 \pm 0.9$ & 68.5 \\
\hline 2 & 1 & 35 & $8.0 \pm 0.9$ & $8.7 \pm 0.8$ & $7.4 \pm 0.4$ & $8.8 \pm 1.0$ & $8.9 \pm 0.6$ & 39.6 \\
\hline 3 & 1 & 40 & $8.3 \pm 0.6$ & $8.9 \pm 0.6$ & $9.86 \pm 0.6$ & $10.9 \pm 0.7$ & $10.1 \pm 0.8$ & 68.9 \\
\hline 4 & 3 & 30 & $8.8 \pm 1.0$ & $8.2 \pm 0.5$ & $9.5 \pm 0.9$ & $10.1 \pm 0.4$ & $8.6 \pm 1.0$ & 86.8 \\
\hline 5 & 3 & 35 & $9.9 \pm 1.0$ & $9.3 \pm 0.9$ & $9.4 \pm 0.6$ & $11.4 \pm 1.0$ & $9.7 \pm 0.6$ & 48.0 \\
\hline 6 & 3 & 40 & $9.6 \pm 0.7$ & $8.9 \pm 1.1$ & $13.3 \pm 4.0$ & $12.7 \pm 0.1$ & $11.5 \pm 1.0$ & 87.3 \\
\hline 7 & 5 & 30 & $8.9 \pm 0.4$ & $11.0 \pm 0.7$ & $10.5 \pm 1.1$ & $11.6 \pm 0.9$ & $11.1 \pm 0.9$ & 115.9 \\
\hline 8 & 5 & 35 & $11.5 \pm 1.5$ & $10.9 \pm 0.8$ & $10.2 \pm 1.7$ & $14.4 \pm 0.5$ & $12.7 \pm 0.6$ & 104.7 \\
\hline 9 & 5 & 40 & $12.3 \pm 1.4$ & $12.6 \pm 0.1$ & $11.4 \pm 1.0$ & $17.1 \pm 1.5$ & $10.7 \pm 1.1$ & 164.0 \\
\hline
\end{tabular}


As it is a microorganism (yeast) crop, the dependence on a series of variables, such as water content, total soluble solids, water activity, $\mathrm{pH}$, fixed mineral waste, among others, will directly influence the development of yeast in the feedstock. The results of each experiment for the water content (\%) and total soluble solids ( ${ }^{\circ}$ Brix), at the beginning of the fermentation and after $72 \mathrm{~h}$ of the process, time in which the highest values of protein increase were reached, are shown in the Table 3.

The water content is an intrinsic factor to the fermentation process in a semi-solid state, with the biotransformation of the samples taking place. Availability of water in the system is of fundamental importance for the biosynthesis of new cells during fermentation (Araújo et al., 2017).

The water content presented by the substrates at the beginning of fermentation for all experiments was greater than $80 \%$, and the samples during the process showed a gradual decrease in this content, caused by water loss through evaporation. This could interfere with the yeast growth, as it reduces the water availability for chemical/enzymatic reactions to occur and decreases the efficiency of cell activity during solid-state fermentation (Santos et al., 2018). However, after 72 hours of processing, the values were still within the optimal range of the water content reported by Thomas et al. (2013) from 30 to $80 \%$.

Experiments 3, 6 and 9 (Table 3) showed the lowest water content after $72 \mathrm{~h}$ of the process, varying between approximately 71.5 to $76.1 \%$. This reduction may be related to the temperature of $40{ }^{\circ} \mathrm{C}$ and the presence of yeast, in which it uses the water present in the medium for promoting the fermentation process. According to Santana Neto et al. (2017), this marked reduction in water content can be explained by specific causes, such as temperature and the trays arrangement in the greenhouse. The final value of water content was higher than what was obtained by Araújo et al. (2017), of $9.03 \%$, for the protein bioconversion of cassava peel by $S$. cerevisiae at temperature ranging from 55 to $65^{\circ} \mathrm{C}$, for a period of $72 \mathrm{~h}$.

The results in relation to the total soluble solids content ('Brix), on a dry basis, (Table 3 ) showed a sharp drop that ranged from 19.0 to $4.1{ }^{\circ}$ Brix during the fermentation of experiments 1, 4 and 7. Campos et al. (2005) studied the protein enrichment using bagasse from the cashew stalk by solid-state fermentation, and according to them, the necessary fermentation time for maximum conversion of the soluble carbohydrates in bagasse was around $24 \mathrm{~h}$. This was evidenced in experiments 2,5 and 8 , with the contents ranging from 22.3 to $6.6^{\circ} \mathrm{Brix}$ and, in experiments 3, 6 and 9, from 33.3 to $7.8^{\circ}$ Brix. High contents are expected, since most of the total soluble solids content present in fruit pulps are also in their wastes. These can also vary with the processing applied in the pulp extraction, climatic factors, fruit variety, types of soil and several other agronomic factors (Uchoa et al., 2008).

According to Silva et al. (2017), the decrease in the values of soluble solids after enrichment was expected, since the fermentative process used provides substrate sugars for protein increase. These same authors, studying the protein enrichment process of the umbu-cajá bagasse using $S$. cerevisiae, through solid-state fermentation, observed a reduction in the soluble solids content in the enriched material during fermentation time, from $0.9 \%$ at time 0 , to $0.5 \%$ at 72 hours.

It was found that the higher the yeast concentration added to the jackfruit peel waste and the higher the fermentation temperature, the higher the protein concentrate content would be, with $72 \mathrm{~h}$ of fermentation. Soon after, a decrease in protein increase took place. This trend is probably associated with the limitation of available carbohydrates, as these are more quickly metabolized when there is a higher concentration of yeasts added to the substrate, according to Campos et al. (2005). The total nutritional depletion in the environment can also be related to it, which results in reduced yeast growth, preventing the conversion of biomass into products and, consequently, reducing the protein increase (Santos et al., 2013).

Table 4 displays the analysis of variance (ANOVA) results for the protein increase that occurred during the solidstate fermentation of the jackfruit peel waste. The yeast concentration factor $\left[C_{L}(L)\right]$ and the fermentation temperature [T (Q)] were significant $(p<0.05)$. All other factors were not significant, as they had a probability greater than 0.05 . The correlation coefficient $\left(R^{2}\right)$ was of $93.10 \%$.

In Equation 3, the second-order coded model obtained from the experimental data established for the yeast

Table 3. Mean \pm standard error of water content (\%) and total soluble solids ( ${ }^{\circ}$ Brix, on a dry basis), at the initial and final times reached with $72 \mathrm{~h}$ of semisolid fermentation of the jackfruit peel waste.

\begin{tabular}{ccccc}
\hline \multirow{2}{*}{ Experiment } & \multicolumn{2}{c}{ Water contente (\%) } & \multicolumn{2}{c}{ Total soluble solids ('Brix) } \\
\cline { 2 - 5 } & Initial & Final & Initial & Final \\
\hline 1 & $82.12 \pm 0.54$ & $76.13 \pm 2.17$ & $19.01 \pm 0.12$ & $7.13 \pm 0.36$ \\
2 & $82.69 \pm 0.75$ & $74.78 \pm 3.85$ & $22.33 \pm 0.10$ & $6.60 \pm 0.43$ \\
3 & $83.01 \pm 0.10$ & $72.04 \pm 3.51$ & $27.07 \pm 0.17$ & $8.15 \pm 0.25$ \\
4 & $82.12 \pm 0.54$ & $75.79 \pm 0.74$ & $16.22 \pm 0.12$ & $4.13 \pm 0.24$ \\
5 & $82.69 \pm 0.75$ & $76.14 \pm 1.22$ & $18.29 \pm 0.25$ & $11.54 \pm 0.41$ \\
6 & $83.01 \pm 0.10$ & $76.03 \pm 0.61$ & $26.09 \pm 0.40$ & $10.87 \pm 0.46$ \\
7 & $82.12 \pm 0.54$ & $75.63 \pm 0.90$ & $13.42 \pm 0.10$ & $4.95 \pm 0.24$ \\
8 & $82.69 \pm 0.75$ & $76.03 \pm 0.66$ & $18.85 \pm 1.59$ & $8.85 \pm 0.48$ \\
9 & $83.01 \pm 0.10$ & $71.56 \pm 1.93$ & $33.31 \pm 1.53$ & $7.84 \pm 0.29$ \\
\hline
\end{tabular}


Table 4. ANOVA results for the Protein Increase.

\begin{tabular}{cccccc}
\hline Factor & Quadratic sum & Degree of freedom & Quadratic mean & $\mathbf{F}$ & $\mathbf{p}$ \\
\hline $\mathrm{C}_{\mathrm{L}}(\mathrm{L})$ & $\mathbf{7 1 8 2 . 9 6}$ & $\mathbf{1}$ & $\mathbf{7 1 8 2 . 9 6 0}$ & $\mathbf{3 6 . 3 4 8 3 6}$ & $\mathbf{0 . 0 0 3 8 1 5}$ \\
$\mathrm{C}_{\mathrm{L}}(\mathrm{Q})$ & 765.71 & 1 & 765.709 & 3.87476 & 0.120384 \\
$\mathrm{~T}(\mathrm{~L})$ & 400.17 & 1 & 400.167 & 2.02499 & 0.227815 \\
$\mathrm{~T}(\mathrm{Q})$ & $\mathbf{2 3 7 5 . 9 0 1}$ & $\mathbf{1}$ & $\mathbf{2 3 7 5 . 9 0 6}$ & $\mathbf{1 2 . 0 2 2 9 2}$ & $\mathbf{0 . 0 2 5 6 4 4}$ \\
Error & 790.46 & 4 & 197.614 & & \\
Total SS & 11515.20 & 8 & & & \\
\hline
\end{tabular}

concentration $\left(C_{L}\right)$ and the fermentation temperature $(T)$ is shown, with the protein increase (PI) as response.

$$
\begin{aligned}
\mathrm{PI} & =48.0+32.55 \mathrm{C}_{\mathrm{L}}+24.15 \mathrm{C}_{\mathrm{L}}^{2}+25 \mathrm{~T}+39.05 \mathrm{~T}^{2}+ \\
& +11.92 \mathrm{C}_{\mathrm{L}} \cdot \mathrm{T}+3.075 \mathrm{C}_{\mathrm{L}} \cdot \mathrm{T}^{2}+11.87 \mathrm{C}_{\mathrm{L}}^{2} \cdot \mathrm{T}-6.87 \mathrm{C}_{\mathrm{L}}^{2} \cdot \mathrm{T}^{2}
\end{aligned}
$$

Regarding the protein increase response, Figure 1, which illustrates the response surface of the influence of yeast concentration and fermentation temperature, is within the range of the studied values, and that the two variables had influences on protein increase, since that temperature has a great influence on the microorganisms growth. The growth process is dependent on chemical reactions that are altered by temperature, which varies according to the microorganism type. Yeast, for example, develops in a temperature range from 20 to $40{ }^{\circ} \mathrm{C}$ (Manikandan \& Viruthagri, 2010), having an optimal growth temperature around $38{ }^{\circ} \mathrm{C}$ and, as the temperature increases, bacterial contamination can be favored, making it more sensitive to the environment toxicity (Torija et al., 2003; Polyorach et al., 2013).

Observing Figure 1 , the temperature of $40{ }^{\circ} \mathrm{C}$ allowed a faster yeast development, at a concentration of $5 \%$ of inoculum, expressing its maximum metabolic potential and, thus, displaying better protein contents for the jackfruit peel waste after $72 \mathrm{~h}$ of solid-state fermentation process.

The highest values of protein increase were found with the maximum values of yeast concentration and temperatures.

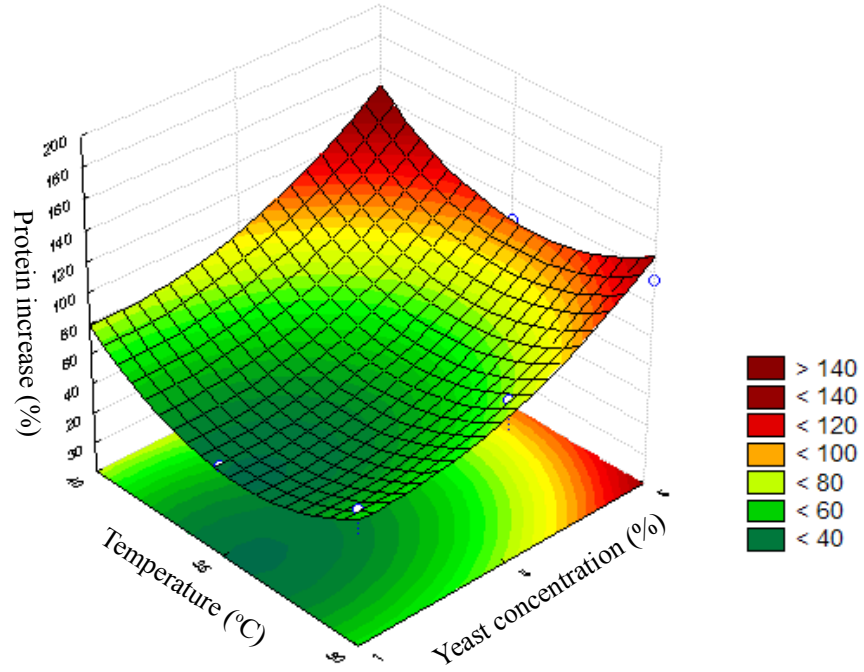

Figure 1. Response surface of the yeast concentration effect versus temperature with a protein increase response.
Analyzing the percentage of found protein gain, we can see that both the yeast concentration and the temperature had influence on the process. According to the values found in Table 2, experiment 9 achieved a greater protein increase of $164 \%$, which corresponded to a maximum crude protein percentage of $17.1 \%$.

Hence, the protein enrichment of jackfruit peel waste through solid-state fermentation by using $S$. cerevisiae, is a viable alternative, contributing to science and humanity, especially for the population from the region close to producers and rural breeders, since the high production means that this fruit is not fully used. Therefore, the surplus can be used as a protein supplement in animal feed through fermentative processing, assisting entrepreneurs in reducing costs, as it is an efficient, low-cost technology and shows positive responses regarding its nutritional value, also adding value to the new product.

\section{Conclusions}

Solid-state fermentation of jackfruit peel waste by using the $S$. cerevisiae yeast increased the protein content and, consequently, the protein increase of the waste in relation to the yeast concentration $(5 \%)$ and temperature $\left(40{ }^{\circ} \mathrm{C}\right)$, obtaining the highest concentration at $72 \mathrm{~h}$ of the fermentation process.

The protein increase was of $164 \%$, corresponding to a crude protein of $17.1 \%$.

The employed process proved to be efficient for the protein enrichment of the used raw material, obtaining a protein supplement that could later be used as an alternative for animal feed.

\section{Literature Cited}

Alexandre, H.V.; Silva, F.L.H.; Gomes, J.P.; Silva, O.S.; Carvalho, J.P.D.; Lima, E.E. Cinética de secagem do resíduo de abacaxi enriquecido. Revista Brasileira de Engenharia Agrícola e Ambiental, v.17, n.6, p.640-646, 2013. https://doi.org/10.1590/ S1415-43662013000600010.

Anaya-Esparza, L. M.; González-Aguilar, G. A.; Domínguez-Ávila, J. A.; Olmos-Cornejo, J. E.; Pérez-Larios, A.; Montalvo-González, E. Effects of minimal processing technologies on Jackfruit (Artocarpus heterophyllus Lam.) quality parameters. Food and Bioprocess Technology, v.11, n.9, p.1761-1774, 2018. https:// doi.org/10.1007/s11947-018-2136-z. 
Araújo, L.F; Aguiar, E. M.; Coelho, R.R.P.; Luciano, R.C.; Bernadino Filho, R.; Navarro, L.A.O. Enriquecimento nutricional da casca da mandioca (Manihot esculenta, crantz) por processo biotecnológico destinado à alimentação animal. Revista Raízes e Amidos Tropicais, v.13, n.1, p.18-30, 2017. https://doi. org/10.17766/1808-981X.2017v13n1p18-30.

Campos, A.R.N.; Santana, R.A.C.; Dantas, J.P.; Oliveira, L.S.C.; Silva, F.L.H. Enriquecimento proteico do bagaço do pedúnculo de caju por cultivo semissólido. Revista de Biologia e Ciências da Terra, v.5, n.2, 2005. http://joaootavio.com.br/bioterra/workspace/ uploads/artigos/caju.-5182de888db41.pdf. 05 Nov. 2018.

Costa, J.A.V.; Treichel, H.; Kumar, V.; Pandey, A. Advances in solidstate fermentation. In: Padey, A.; Larroche, C.; Soccol, C.R. (Eds.). Current developments in biotechnology and bioengineering. Amsterdan: Elsevier, 2018. Chap. 1, p.1-17, 2018. https://doi. org/10.1016/B978-0-444-63990-5.00001-3.

Feitosa, R.M.F.; Queiroz, A.J.M.; Figueirêdo, R.M.F.; Melo, J.C.S. Avaliação físico-química e sensorial de amêndoas de jaca cozida. Revista de Ciências Agroambientais, v.15, n. 1, p.83-89, 2017. https://periodicos.unemat.br/index.php/rcaa/article/ view/2200/1791. 11 Nov. 2018.

Godoy, M. G.; Amorim, G. M.; Barreto, M. S.; Freire, D. M.G. Agricultural residues as animal feed: protein enrichment and detoxification using solid-state fermentation. In: Padey, A.; Larroche, C.; Soccol, C.R. (Eds.). Current developments in biotechnology and bioengineering. Amsterdan: Elsevier, 2018. Chap. 12, p.235-256. https://doi.org/10.1016/B978-0-444-63990-5.00012-8.

Haque, M. A.; Begum, R.; Shibly, A. Z.; Sultana, M. M.; Khatun, A. Influence of jackfruit pulp on the quality and shelf life of jackfruit cake. Journal Environmental Science and Natural Resources, v.8, n.1, p.59-64, 2015. https://doi.org/10.3329/jesnr.v8i1.24672.

Instituto Adolfo Lutz - IAL. Métodos físico-químicos para análise de alimentos. 4.ed. São Paulo: IAL, 2008. 1020p. http:// www.ial.sp.gov.br/resources/editorinplace/ial/2016_3_19/ analisedealimentosial_2008.pdf. 06 Set. 2018.

Manikandan,K.; Viruthagiri,T. Optimization of $\mathrm{C} / \mathrm{N}$ ratio of the medium and fermentation conditions of ethanol production from tapioca starch using co-culture of Aspergillus niger and Saccharomyces cerevisiae. International Journal of ChemTech Research, v.2, n.2, p.947-955, 2010. http://sphinxsai.com/s_v2_n2/CT_V.2No.2/ ChemTech_Vol_2No.2_pdf/CT=32\%20(947-955).pdf. 12 Out. 2018.

National Research Council - NRC. Nutrient requirements of domestic animals. Washington: National Academies Press, 1989. 100p.

United Nations - ONU. Department of Economic and Social Affairs. World Population

Prospects 2019. Volume I: Comprehensive Tables. New York: ONU, 2019. 374 p. https://population.un.org/wpp/Publications/ Files/WPP2019_Volume-I_Comprehensive-Tables.pdf. 29 Jul. 2019.
Pelizer, L.H.; Pontieri, M.H.; Moraes, I.O. Utilização de resíduos agroindustriais em processos biotecnológicos como perspectiva de redução do impacto ambiental Journal of Technology Management \& Innovation, v. 2, n. 1, p. 118-127, 2007. https://www.jotmi.org/ index.php/GT/article/view/art41/395. 05 Nov. 2018.

Polyorach, S.; Wanapat, M.; Wanapat, S. Enrichment of protein content in cassava (Manihot esculenta Crantz) by supplementing with yeast for use as animal feed. Emirates Journal of Food and Agriculture, v. 25, n. 2, p. 142-149, 2013. https://doi.org/10.9755/ejfa.v25i2.10649.

Rosales, E.; Pazos, M.; Sanromán, M. A. Solid-state sermentation for food applications. In: Padey, A.; Larroche, C.; Soccol, C.R. (Eds.). Current developments in biotechnology and bioengineering. Amsterdan: Elsevier, 2018. Chap. 15, p.319-355, 2018. https:// doi.org/10.1016/B978-0-444-63990-5.00015-3.

Santana Neto, D.C.; Onias, E.A.; Araújo, J.S.F.; Alves, A.M.A.; Silva, O.S. Avaliação do processo de enriquecimento proteico de resíduo de abacaxi. Revista Verde de Agroecologia e Desenvolvimento Sustentável, v.12, n.1, p.95-99, 2017. https://doi.org/10.18378/ rvads.v12i1.4625.

Santos, P.S; Solidade, L.S.; Souza, J.G.B.; Lima, G.S.; Braga Júnior, A.C.R.; Assis, F.G.V.; Leal, P.L. Fermentação em estado sólido em resíduos agroindustriais para a produção de enzimas: uma revisão sistemática. The Journal of Engineering and Exact Sciences, v.4, n.2, p.181-188, 2018. https://doi.org/10.18540/jcecvl4iss2pp0181-0188.

Santos, T.C.; Rocha, T.J.O.; Oliveira, A.C.; Abreu Filho, G.A.; Franco, M. Aspergillus niger como produtor de enzimas celuloliticas a partir farelo de cacau (Theobroma cacao). Arquivos do Instituto Biológico, v.80, n.1, p.65-71, 2013. https://doi.org/10.1590/ S1808-16572013000100010.

Silva, J.L.; Silva, O.S.; Alves, F.M.S.; Vieira, N.C.; Nascimento, A.M. Enriquecimento proteico de resíduo de umbu-cajá empregando fermentação semissólida. Revista Verde de Agroecologia e Desenvolvimento Sustentável, v.12, n.5, p.854-857, 2017. https://doi.org/10.18378/rvads.v12i5.5572.

Statsoft. Statistica (data analysis software system), version 8. 2007. https://statistica.software.informer.com/8.0. 12 Oct. 2018.

Thomas, L.; Larroche, C.; Pandey, A. Current developments in solidstate fermentation. Biochemical Engineering Journal, v. 81, p. 146-161, 2013. https://doi.org/10.1016/j.bej.2013.10.013.

Torija, M. J., Rozes, N., Poblet, M., Guillamon, J.M., Mas, A. Effects of fermentation temperature on the strain population of Saccharomyces cerevisiae. International Journal of Food Microbiology, v.80, n.1, p. 47-53, 2003. https://doi.org/10.1016/ S0168-1605(02)00144-7

Uchoa, A.M.A.; Costa, J.M.C; Maia, G.A.; Silva, E.M.C.; Carvalho, A.F.F.U.; Meira, T.R. Parâmetros físico-químicos, teor de fibra bruta e alimentar de pós alimentícios obtidos de resíduos de frutas tropicais. Segurança Alimentar e Nutricional, v. 15, n.2, p. 58-65, 2008. https://periodicos.sbu.unicamp.br/ojs/index.php/ san/article/view/1817/1870. 11 Nov. 2018. 